\title{
Enzymatic Deinking on Mixed Office Waste (MOW) Papers
}

\author{
Hamidreza Allahvakil ${ }^{1}$, Babak Nikravesh ${ }^{1}$, Marziyeh Khatibzade ${ }^{1}$, Hashem Vajar ${ }^{1}$, Armina Abbasi ${ }^{1}$, and Parisa \\ Najmi $^{1}$
}

\begin{abstract}
In this work deinking was done using enzymatic deinking method. In order to obtain desirable papers, deinking was done on mixed office waste (MOW) papers, which are difficult to recycle regarding to their ink type and printing process. After that hand sheets were made out of the paper pulp and optical and mechanical tests were performed to reach optimum results.
\end{abstract}

Keyword--Mixed office waste paper, enzymatic deinking

\section{INTRODUCTION}

$\mathrm{R}$ ECYCLING of waste paper is an alternative process which can preserve the green plants and saves the environment in terms of pollution, water and energy [1]. Recycling of waste paper requires the removal of printing ink from the paper by a process called deinking. Deinking which involves the removal of printing ink, mainly consists of two steps i.e. the detachment of ink particles from the fiber surface followed by the removal of detached ink from the pulp slurry by washing or floatation [2]. Traditionally chemical methods have been utilized for deinking but recently the use of enzymes has proven to be a possible and competitive strategy to deink recycled pulps. However a thorough enzyme selection and the optimization of the process are needed in order to accomplish a good quality final product [3]. The enzymatic deinking of different types of waste paper demonstrated a high efficiency of $86.6 \%$ on laser-printed paper, but a low dinking efficiency of $12.9 \%$ was obtained with newspaper [4]. Paper, as one of the largest solid waste materials, is relatively easy and inexpensive to recycle. The recycling of waste papers diminishes environmental pollution by reducing the flow of waste papers to landfills. Recycled and reused waste papers are important low-cost fiber resources (raw materials) for the pulp and paper industry [5]. Mixed office waste paper is a fast growing source of materials for recycling and the most difficult raw material for deinking [6,7]. One of the benefits of using enzymes in deinking is the minimum treatment of effluent produced due to lower in COD content compared with chemical deinking process [8].

\footnotetext{
${ }^{1}$ Department of Polymer Engineering and Colour Technology, Amirkabir University of Technology
}

Therefore the aim of this article is to characterize two types of enzymatically deinked waste paper, including laserprinted paper and photocopy paper to provide further insight into the effects of enzymatic activity on waste papers and study the enzymatic deinking process which can improve the quality of recycled paper better.

\section{MATERIALS AND METHODS}

According to the studies in the past, several enzymatic deinking mechanisms can be used depending on the type of the enzymes we are using. Effective kinds of enzymes for this purpose include lipase, estrase, pectinase, hemi cellulose, cellulase and lignolytic enzyme. Enzymes such as pectinase, cellulase, hemicellulase and lignolytic modify the fiber's surface or chemical or physical bonds around ink components and therefore ink particles would be detached to be removed by washing or flotation methods.

Every experiment was done using a mixture of $2 * 2 \mathrm{~cm} 2$ pieces of paper including $70 \%$ photocopy prints and $30 \%$ laser prints. A blender, which is a container with a blade at its bottom and distilled water was added to the container until it reached 1liter so that we could have a mixture with $4 \%$ consistency. The mixture was blended for overall time of 15 minutes. Removing ink particles from the fiber is the most important step of enzymatic deinking process. Celluzyme $0.7 \mathrm{~T}$ (E1) and celluclast $1.5 \mathrm{~L}$ (E2) were two types of enzymes from cellulase familly that were obtained from Novozymes company. A solution of $1 \%$ consistency was made by adding distilled water to enzymes. In order to the optimum $\mathrm{PH}$ (7-7.3) for enzymatic reactions, a few drops of sulfuric acid (2molar) and a non-ionic surfactant (simulsol) was added to the solution. The solution was mixed for 30 minutes at $55^{\circ} \mathrm{C}$. After enzymatic treatment, the obtained pulp should be boiled for 10 minutes in order to deactivate the enzymes. In order to remove ink from the pulp solution, we have used the flotation method, which is the use of a cylindrical container with a total volume of 4 liters in which the air was pumped by plastic pipes with volumetric flow rate of 2 lit/min for 10 minutes. The air particles have a tendency to attach to hydrophobic part of ink particles and they carry the particles to the surface of the cell and produce foam which will be removed afterwards. The remaining paste had to be turned into hand sheets, using a laboratory handsheet maker machine containing two vacuuming and heating parts according to 


\section{ISO 5269-1 standard.}

In this research optical properties such as brightness (ISO 4094), whiteness (using stensby formula), yellowness (ASTM E 313-73) and mechanical properties as tensile index (ISO 1924-2), burst index (ISO 2758) and drainage rate (ISO 5267-1) were measured and compared to control samples which were not deinked.

\begin{tabular}{|c|c|c|c|c|c|c|}
\begin{tabular}{|c|c|c|c|} 
TABst \\
sampla
\end{tabular} & Brightness (\%) & $\begin{array}{c}\text { Whiteness } \\
(\%)\end{array}$ & $\begin{array}{c}\text { Yellowness } \\
(\%)\end{array}$ & $\begin{array}{c}\text { Drainage } \\
\text { rate('SR) }\end{array}$ & $\begin{array}{c}\text { Burst } \\
\left.\text { index(KPam } \mathrm{m}^{2} / \mathrm{g}\right)\end{array}$ & $\begin{array}{c}\text { Tensile } \\
\text { index(NM/g) }\end{array}$ \\
\hline Control & 92.31 & 59.47 & 4.81 & 23 & 2.109 & 37.35 \\
\hline E1 & 99.68 & 56.31 & 6.599 & 27 & 2.187 & 35.209 \\
\hline E2 & 99.12 & 57.6 & 6.131 & 30 & 2.218 & 40.68 \\
\hline
\end{tabular}

\section{RESULTS AND CONCLUSION}

One of the most important results of enzymatic deinking is the increase in drain ability of recycled papers. Papers which were recycled using this method can be used to manufacture tissues and other hygienic materials. According to the test results, type E1 enzyme showed better optical characteristics. It can be seen that whiteness has decreased using either one of enzymes which was predictable because considering enzymatic deinking mechanism, when microfibrils are detached from the surface of the hand sheets to separate ink particles from the surface, they also take an amount of inorganic fillers such as talc and calcium carbonate to the surface of flotation cell which will be removed later. Therefore a small amount of fillers and whiteners is lost during deinking process by this method.

Considering the drainage rate, which is resistance of fiber against flow of water, it was observed that drainage rate of E2 enzyme was more than the other samples that was due to loss of more microfibrils during its deinking process that leads to increase of free space between fibers. It is notable that these results are only limited to these two types of enzymes (E1, E2) which have been used in this experiment and better or worse results may be achieved by using other types of enzymes.

With regard to environmental issues and threat of water pollution using chemical deinking methods and also better deinking ability of enzymes for MOW papers, this method is a suitable and developing system in industrial scale which can compete with chemical deinking methods for MOW papers.

\section{REFERENCES}

[1] S. Imamoglu, "Deinking efficiency of waste office paper printed using a duplicating machine," Applied Science, vol. 6, pp. 2006-2009, 2006. http://dx.doi.org/10.3923/jas.2006.2006.2009

[2] A. Singh , R. D. Yadav, A. Kaur, R.Mahajan, "An ecofriendly cost effective enzymatic methodology for deinking of school waste paper," Bioresource Technology,vol. 120, pp. 322-327, September 2012. http://dx.doi.org/10.1016/j.biortech.2012.06.050

[3] H. Pala, M. Mota, F.M. Gama, "Enzymatic versus chemical deinking of non-impact ink printed paper," Journal of Biotechnology, vol. 108, pp. 79-89, 2004.

[4] C. K. Lee, D. Ibrahima, I. C. Omarb, "Enzymatic deinking of various types of waste paper: Efficiency and characteristics," Process Biochemistry, vol. $\quad 48, \quad$ pp.299-305, 2013. http://dx.doi.org/10.1016/j.procbio.2012.12.015

[5] Malaysian Newsprint Industries Sdn Bhd (2007). Online available from World Wide Web: http://www.newsprint.com.my [accessed 30.10.12].

[6] G. M. Gubitz, S. D. Mansfield, D. Bohm, J. N. Saddler, " Effect of endoglucanases and hemicellulases in magnetic and flotation deinking of xerographic and laser- printed papers," Journal of Biotechnology, vol 65, pp. 209-215, October 1998. http://dx.doi.org/10.1016/S01681656(98)00130-8

[7] D. Y. Prasad, "Enzymatic deinking of laser and xerographic office wastes," ISSN.on Appita, vol. 46, pp. 289-292, 1993.

[8] H. J. Putz, K. Renner, L. Gottsching, O. Jokinen, “ Enzymatic deinking in comparison with conventional deinking offset news," in Proc.1944 Tappi Pulp Conf., 1994, pp. 877-877 